\title{
PENGARUH PERSEPSI KARIER DAN KEDISIPLINAN TERHADAP PRESTASI KERJA
}

\author{
Oleh: \\ Widodo \\ Sekolah Tinggi Ilmu Ekonomi IPWI Jakarta \\ Email: widodomursanih@gmail.com
}

\begin{abstract}
ABSTRAK
Penelitian bertujuan untuk menjawab perumusan masalah : (a) Apakah terdapat pengaruh Persepsi Karier terhadap Prestasi Kerja? (b) Apakah terdapat pengaruh Kedisiplinan terhadap Prestasi Kerja? (c) Apakah terdapat pengaruh antara pengaruh Persepsi Karier dan Kedisiplinan terhadap Prestasi Kerja?

Penelitian ini merupakan studi pustaka terhadap Persepsi karier, Kedisiplinan dan Prestasi Kerja. Metode yang dilakukan dengan memperguakan penelitian deskriptif kuantitaif.

Hasil penelitian menunjukan bahwa secara bersama-sama terdapat pengaruh yang signifikan antara variabel Persepsi karier (X1) dan variabel Kedisiplinan (X2) terhadap variabel Prestasi Kerja $(Y)$.

Saran yang ditujukan adalah harus meningkatkan persepsi karier, meningkatkan Kedisiplinan dan meningkatkan Prestasi Kerja.

Kata kunci:

Persepsi karier, Kedisiplinan dan Prestasi Kerja

Submit: 30 November 2018

Review: 30 April 2019

Publish: 30 April 2019

\section{PENDAHULUAN}

Zaman semakin berkembang maka persaingan semakin ketat sehingga presepsi karier dalam organisasi sangat penting dan menjadi kewajiban utama bagi setiap pegawai untuk selalu terus menerus berusaha, mengamati, memahami dan mengikuti perkembangan zaman, mencari dan menentukan terjadinya tingkah laku dan tindakan, oleh karena itu setiap manusia ingin menjadi lebih maju, labih baik dan lebih berkembang bahkan

kemajuan dalam bidang keahliannya. Untuk mendapatkan dan mencapai citacita itu haruslah berusaha dan mempunyai presepsi tentang apa yang akan dicapai. Selain itu harus dipikirkan tentang karier

Apabila dikatakan bahwa sumber daya manusia merupakan sumber daya terpenting yang dimiliki oleh suatu organisasi, salah satu implikasinya ialah bahwa investasi terpenting yang mungkin dilakukan oleh suatu organisasi adalah di bidang sumber daya manusia. Pertanyaan
\end{abstract}


yang dihadapi dan harus dijawab oleh setiap organisasi bukan lagi apakah akan melakukan investasi dalam rangka pengembangan sumberdaya manusia yang dimilikinya, melainkan berapa besar investasi yang harus dibuat untuk mecapai karier, kedisiplinan dan prestasi kerja.

Apabila tanpa presepsi dan kedisiplinan yang baik, maka organisasi atau lembaga akan kesulitan mencapai prestasi kerja yang optimal. Rasa tanggung jawab seseorang terhadap tugas-tugas yang diberikan kepadanya tanpa disiplin tidaklah dapat mendorong suatu gairah kerja, semangat kerja, dan mendukung terwujudnya tujuan dari organisasi, sehingga disiplin yang baik adalah mencerminkan besarnya rasa tanggung jawab.

Dengan demikian untuk peningkatan dan kelancaran pelaksanaan pembangunan baik fisik maupun nonfisik maka pegawai dalam melakukan pekerjaannya sering menjadi persoalan sulit yang dihadapi oleh suatu lembaga atau organisasi yang berkaitan erat dengan Presepsi karier, kedisiplinan dan prestasi kerja harus dilakukan melalui sistem penilaian atas pelaksanaan tugas dan pekerjaannya sehingga tujuan dan target yang direncanakan akan dapat dicapai secara optimal

Pada perkembangan teknologi dan informasi yang semakin maju ini maka organisasi harus berusaha dengan dilandasi ketergantungan (Depedency) dan keperkiraan (Proximity) sebagai akibat kemajuan teknologi dan perkembangan penduduk, sehingga pengertian organisasi berkembang mengikuti interaksi antara sistem formal dengan komponenkomponen manusia. Maka organisasi pada dinas pendidikan merupakan wadah yang berfungsi menyelenggarakan proses pendidikan.
Kedisiplinan sebagai proses psikologis timbul diakibatkan oleh faktor di dalam diri seseorang itu sendiri yang disebut intrinsik dan faktor diluar diri seseorang disebut faktor ektrinsik. Faktor di dalam diri seseorang dapat berupa kepribadian, sikap, pengalaman, dan pendidikan, atau berbagai harapan, cita-cita yang menjangkau masa depan.

Dengan tidak mengesampingkan aspirasi dan harapan para pegawai yang akan dipimpinnya. Karena sering terjadi pimpinan beralasan dari dinas atau lembaga lain yang tidak dikenal sebelumnya oleh para pegawai yang memiliki basic, kedisiplinan, kompetensi, serta kualitas kepemimpinan maupun sikap individunya.

Berdasarkan latar belakang masalah tersebut, maka penulis menganggap penting untuk mengkaji masalah Presepsi Karier dan Kedisiplinan terhadap Prestasi Kerja pada SMP Negeri 21 Depok, hal itu penulis lakukan karena untuk mengamati permasalahan yang terjadi serta mencari jalan keluar yang terbaik.

\section{TUJUAN PENELITIAN}

Menganalisis pengaruh Presepsi karier dan Kedisiplinan terhadap Prestasi kerja

\section{TELAAH LITERATUR DAN PENGEMBANGAN HIPOTESIS Persepsi Karir}

Presepsi karier Menurut Sondang P. Siagian (2002: hal.182) mengatakan bahwa: "Pelatihan dan pengembangan mutlak perlu dilakukan, kemutlakan itu tergambar pada jenis manfaat yang dapat dipetik dari padanya baik bagi organisasi, bagi para pegawai maupun bagi penumbuhan dan peliharaan hubungan yang serasi antar berbagai kelompok kerja dalam suatu organisasi". 
Pengembangan karyawan sebaiknya dilakukan secara terencana dan berkesinambungan supaya pengembangan ini dapat dilaksanakan dengan baik. Pengembangan (development) adalah fungsi operasional kedua dari manejemen personalia, maka pengembangan sebaiknya lebih dahulu ditetapkan dengan sangat terencana yang berkaitan dengan pengembangan karyawan / pegawai.

"Pengembangan karyawan ini dirasakan semakin penting manfaatnya karena tuntutan pekerjaan atau jabatan sebagai akibat kemajuan teknologi dan semakin ketatnya persaingan diantara perusahaan yang sejenis. Setiap personil perusahan dituntut agar dapat bekerja efektif, efesien, kwalitas dan kwantitas pekerjaannnya sehingga daya saing perusahaan semakin besar. Pengembangan ini dilakukan bagi karyawan melalui latihan dan pendidikan"

Pengembangan

karyawan membutuhkan biaya yang sangat besar yang erat kaitannya terhadap kelanjutan karier bagi pegawai atau karyawan itu, karena dalam hal ini pimpinan dari instansi maupun dari perusahaan semakin sangat menyadari bahwa sangat perlu pengembangan karier bagi pegawainya. Walaupun biaya cukup besar, tetapi biaya itu merupakan investasi jangka panjang.

Selanjutnya yang berhubungan dengan pengembangan karier adalah: "Development, in reference to staffing and personnel matters, is a long term educational process utilizing a systematic and organized procedure by which managerial personnel learn conceptual and theoretical knowledge for general purposes (Steinmetz)". (Andrew F. Sikula dalam Melayu Hasibuan, 1997 : hal. 77).

Selanjutnya dikemukakan oleh Jan Bella dalam Melayu Hasibuan bahwa: "Pendidikan dan pelatihan sama dengan pengembangan, yaitu merupakan proses peningkatan ketrampilan kerja yang baik teknis maupun menejerial ".

Menurut pendapat tersebut diatas, jelaslah pelatihan dan pendidikan adalah merupakan salah satu alternatif adari pengembangan karier seseorang, baik merupakan jangka pendek maupun jangka panjang dengan menggunakan secara sistematis dan terorganisir.

\section{Kedisiplinan}

Gering Supriyadi (2000:h.44) mengatakan : "Disiplin merupakan sikap yang menggambarkan kepatuhan pada suatu aturan, atau ketentuan yang berlaku dan suatu kemajuan dan perkembangan". Tingkat kedisiplinan pegawai dalam melakukan pekerjaannya sering menjadi persoalan yang sulit yang dihadapi oleh suatu lembaga atau organisasi. Sedangkan lembaga telah menentukan tujuan yang ingin dicapai serta target yang harus diraih. Tujuan dan target yang telah direncanakan ini akan terwujud jika pegawai memiliki tingkat disiplin yang tinggi dalam melaksanakan tugas dan pekerjaannya.

Untuk meningkatkan kedisiplinan pegawai dalam bekerja perlu ditetapkannya peraturan yang tegas dan mampu untuk dilaksanakan. Apabila setiap aturan yang berlaku mampu membatasi perilaku pegawai yang tidak terpuji, dan penegakan sanksi secara tepat maka dengan sendirinya tingkat kedisiplinan pegawai akan semakin baik. Sanksi yang tidak ditegakkan merupakan peraturan yang mandul, dan tidak akan membawa kemajuan pada lembaga atau organisasi.

Dari pendapat di atas tersebut, jelas diuraikan bahwa kedisiplinan akan terwujud dalam diri pegawai apabila di dalam lembaga tersebut terdapat peraturan yang mengikat dan memberikan 
rambu-rambu kepada para pegawai dalam setiap tindakannya.

\section{Prestasi Kerja}

Tujuan manajemen sumber daya manusia adalah untuk meningkatakan dukungan dalam mencapai tujuan organisasi melalui peningkatan produktivitas pegawai sekaligus meningkatkan kepuasan kerja pegawai. Menurut Efendi Hariandja (2002: h. 289) mengatakan bahwa : "Hal yang dipahami untuk meningkatkan prestasi kerja berawal dari sebab kepuasan kerja merupakan satu unsur penting untuk memotivasi kerja dalam mengembangkan keunggulan bersaing yang terus berubah".

Steven P. Robbin dalam Marihot (2002: 291) mengatakan bahwa : "Pekerjaan bukan hanya sekedar melakukan pekerjaan tetapi terkait juga dengan aspek lain seperti interaksi dengan rekan sekerja, atasan, megikuti aturan-aturan, dan lingkungan kerja tertentu yang sering kali tidak memadai atau kurang disukai". Pengertian prestasi kerja menurut Hasibuan (1997: 105) mengatakan: "Prestasi kerja adalah suatu hasil yang dicapai seseorang dalam melaksanakan tugas-tugas yang dibebankan kepadanya yangdidasarkan atas kecakapan, pengalaman, dan kesungguhan serta waktu. Prestasi kerja ini adalah gabungan dari tiga faktor penting, yaitu kemampuan dan minat seorang pekerja ... semakin tinggi ketiga faktor di atas maka semakin besarlah prestasi kerja pegawai yang bersangkutan".

Prestasi kerja karyawan dinilai dari kerja seseorang pegawai yang didasarkan dari pelaksanaan uraian pekerjaan setiap individu. Sedangkan kerja mengandung arti : "Kerja adalah pengorbanan jasa jasmani dan pikiran untuk menghasilkan barang-barang atau jasa-jasa dengan memperoleh imbalan prestasi tertentu."

\section{METODE PENELITIAN \\ Tempat Penelitian dan waktu}

Penelitian ini dilaksanakan di SMP

Negeri 21 Kota Depok. pada tahun 2018.

\section{Jenis Penelitian}

Penelitian yang dilakukan oleh Penulis adalah penelitian untuk melihat ada hubungan atau tidak diantara variabel yang diteliti, oleh karena itu jenis penelitan yang digunakan adalah penelitian survey.

Dalam hal penelitian ini Kerlinger (dalam Sugiyono, 2001) mengatakan bahwa: "Penelitian survey adalah penelitian yang dilakukan pada populasi besar maupun kecil, tetapi data yang dipelajari adalah data dari sampel yang diambil dari populasi tersebut, sehingga ditemukan kejadian-kejadian relatif, distribusi, dan hub ungan-hubungan antar variabel, sosialogis dan psikologis".

Dengan menggunakan jenis penelitian ini diharapkan mampu menggali informasi tentang Kepemimpinan Presepsi Karier dan disiplin Kerja terhadap Kinerja Guru, dalam hal ini seluruh guru sebagai anggota dari SMP Negeri 21 Depok, serta akan diperoleh gambaran tingginya korelasi diantara variabel-variabel tersebut.

\section{Sampel Penelitian}

Populasi dalam penelitian ini adalah Guru pada SMP Negeri 21 Depok. Mengenai pengertian populasi, Sugiono (2001:h.57) mengatakan bahwa : "Populasi adalah wilayah generalisasi yang terdiri atas obyek atau subyek yang mempunyai kwalitas dan karakteristik tertentu yang ditetapkan oleh peneliti untuk dipelajari dan kemudian ditarik kesimpulannya". Suharsimi Arikunto (2002:h.115) mengatakan bahwa : "Populasi adalah keseluruhan obyek penelitian, apabila seseorang ingin meneliti semua elemen yang ada dalam wialyah penelitian maka 
penelitiannya merupakan penelitian populasi".

Besarnya sampel belum ada aturan yang tegas dan jelas tentang besar atau jumlah sampel dalam satu penelitian. Suharsimi Arikunto (2002: 120) mengatakan bahwa : "Untuk sekedar ancer-ancer maka apabila subyeknya kurang dari 100, lebih baik diambil semua sehingga penelitiannya merupakan penelitian populasi. Selanjutnya jika jumlah subyeknya besar dapat diambil antara 10-15\%, atau 20-25\% atau lebih.

Menurut pendapat tersebut di atas, bila subjeknya kurang dari 100, maka penulis tidak menentukan sampel dalam melakukan penelitian, karena subjek yang merupakan populasi kurang dari 100, maka penulis mengambil semua, sehingga penelitian merupakan penelitian total populasi.

Sebagaimana pendapat-pendapat tersebut diatas, dapat disimpulkan bahwa populasi itu adalah obyek penelitian secara keseluruhan yang memiliki karakteristik yang sama. Selanjutnya populasi penelitian ini sebanyak 51 orang, tenaga pengajar (Guru), maka 51 orang untuk dijadikan sampel penelitian bertindak selaku responden atau sebagai sumber data.

\section{Pengumpulan Data}

Guna mengumpulkan data-data yang ada di lapangan, maka Penulis menggunakan beberapa teknik, yaitu yang terdiri dari :

1. Kuisioner (angket)

Teknik kuisioner atau angket ini adalah teknik pengumpulan data dengan menggunakan daftar pertanyaan yang telah disusun yang kemudian disebarkan kepada responden. Dalam hal ini Suharsimi Arikunto (1998:h.140) mengatakan “Kuesioner adalah sejumlah pertanyaan tertulis yang digunakan untuk memperoleh informasi dari responden dalam arti laporan tentang pribadinya, atau hal-hal yang ia ketahui". Sedangkan jenis angket yang digunakan adalah angket tertutup, yakni angket dimana daftar pertanyaan disusun dengan diberikan langsung alternatif jawabannya, sehingga responden hanya tinggal memilih satu dari sejumlah alternatif pilihan.

2. Wawancara (Interview).

Teknik ini yaitu dimana peneliti mengajukan pertanyan kepada responden secara langsung (lisan) tentang hal-hal yang berhubungan dengan masalah yang diteliti. Teknik ini dipergunakan guna mengumpulkan data-data yang bersifat data pendukung, seperti misalnya data tentang gambaran lokasi penelitian serta kegiatan apa yang dilakukan oleh instansi tersebut.

3. Dokumentasi

Studi dokumentasi adalah penelitian dengan cara membaca, mengkaji dan memahami sumber-sumber data dalam bentuk buku, grafik, tabel, gambar, laporan, jurnal, dan dokumen lainnya, yang ada hubungannya dengan permasalahan yang diteliti. Seperti halnya teknik interview, teknik ini dipergunakan untuk mengumpulkan data-data pendukung.

\section{Analisis Data}

Guna menganalisis hubungan Presepsi karier dan Disiplin Kerja terhadap Kinerja Guru di SMP Negeri 21 Depok, penelitian ini akan mempergunakan teknik analisis secara teknik kuantitatif (Statistik).

1. Analisis Statistik Deskriftif

Jenis Analisis ini akan dipergunakan untuk menganalisis data-data pendukung. Dalam hal teknik analisa 
data jenis ini, Suparmoko (1991:h.63) mengatakan: "Statistik Deskriftif yang umum dipakai adalah berupa distribusi frekuensi. ... Cara yang paling sering dipakai dalam analisis data adalah frekuensi distribusi relatif artinya data dibagi dalam beberapa kelompok dan dinyatakan atau diukur dalam presentase. Dengan cara ini kita dapat mengetahui kelompok mana yang paling banyak jumlahnya yaitu ditunjukkan dengan nilai presentase yang tertinggi, dan demikian sebaliknya".

2. Analisis Statistik Inferensial

Analisis jenis ini khusus dipergunakan untuk menganalisis data-data yang diperoleh melalui angket yang dijaring dari responden. Sugiono (2001: 113) mengatakan: "Statistik Inferensial, sering juga disebut statistik induktif atau statistik probabilitas, adalah teknik statistik yang digunakan untuk menganalisa data sampel dan hasilnya diberlakukan untuk populasi. Statistik ini akan cocok digunakan bila sampel diambil dari populasi yang jelas, dan teknik pengambilan sampel dari populasi itu dilakukan secara benar".

\section{Operasionalisasi Variabel}

Operasional variabel menurut pendapat Mohammad Musa dan Titi Nurfitri (1988:h.21) mengatakan bahwa : "Setelah variabel-variabel di Identifikasi dan diklasifikasikan maka variabelvariabel tersebut perlu pula di defenisikan secara operasional".

a. Presepsi Karier (X1)
1. Kesiapan Guru dalam menjalankan tugas
2. Sikap presepsi Guru terhadap karier
3. Dunia Pendidikan dapat menjanjikan suatu peningktan karier

4. Sikap tenaga professional dalam pelaksanaan pekerjaan.

5. Perencanaan sesuai dengan pelaksanaan keprofesionalan

6. Pencapaian karier

7. Presepsi yang dimiliki oleh seorang guru

8. Dalam mencapai karier harus memiliki minat dalam bidang yang ditekuni

9. Dalam meniti karier seorang guru harus memiliki suatu pengetahuan

10. Presepsi karier perlu berhubungan dengan disiplin dan kinerja

b. Variabel Disiplin Kerja (X2)

1. Pulang mengajar tepat waktu

2. Pekerjaan tidak sesuai dengan waktu yang telah ditetapkan

3. Selalu menjalankan tugas sesuai dengan peraturan yang ada

4. melaksanakan tugas sesuai jadwal secara optimal

5. Penyusunan rencana kerja

6. Menjalankan pekerjaan sesuai dengan rencana kerja

7. memberitahukan kepada atasan ketika tidak dapat hadir

8. Selalu mengisi daftar hadir

9. Membaca buku dalam menambah wawasan

10. Selalu memberikan pokok bahasan setiap tugas atau mengajar

c. Prestasi Kerja (Y)

1. Mampu dan berinisiatif untuk menjalankan pekerjaan

2. Menyikapi pengambilan nilai

3. Mempertahankan pengambilan nilai.

4. Dasar dan patokan jam kerja

5. Dalam bekerja mengikuti prosedur

6. Motivasi dari atasan 
7. Menyukai pekerjaan yang bersifat menantang

8. Tanggap dan tanpa menunggu perintah atasan

9. Tanpa berpatokan jam kerja saja

10. Tetap bekerja dan loyal

\section{HASIL PENELITIAN DAN \\ PEMBAHASAN \\ Analisis Deskriptif}

Statistic deskriptif dari jumlah responden $51(\mathrm{~N}=51)$ adalah sebabagi berikut :

1. Standar Deviasi atau penyimpangan pada variabel Presepsi Karier (X1) adalah 4.36357 dengan skor minimum 33.00, mean atau nilai tengah 40.1961 dan skor maksimum 48.00 .

2. Standar Deviasi atau penyimpangan pada variabel Kedisiplinan (X1) adalah 3.80186 dengan skor minimum 33.00, mean atau nilai tengah 40.4706 dan skor maksimum 48.00.

3. Standar Deviasi atau penyimpangan pada variabel Prestasi Kerja Guru (Y) adalah 3.95216 dengan skor minimum 32.00, mean atau nilai tengah 38.9804 dan skor maksimum 49.00.

\section{Presepsi Karier (X1) dan Prestasi Kerja (Y),}

Berdasarkan hasil pengolahan data memperoleh hasil 0,456, lebih besar dari Harga Kritik dari Spearmen, N=30 dengan tingkat kepercayaan 95\% yaitu 0,364 berarti secara parsial terdapat pengaruh yang signifikan antara Presepsi Karier (X1) terhadap Prestasi Kerja (Y).

\section{Kedisiplinan (X2) dan Prestasi Kerja (Y).}

Berdasarkan hasil pengolahan data memperoleh hasil 0,443, lebih besar dari Harga Kritik dari Spearmen, N=30 dengan tingkat kepercayaan 95\% yaitu 0,364 berarti secara parsial terdapat pengaruh yang signifikan Kedisiplinan (X2) terhadap Prestasi Kerja (Y).

\section{Presepsi Karier (X1) dan Kedisiplinan (X2) Serta Prestasi Kerja (Y),}

Berdasarkan hasil pengolahan data melalui program Statistical Product and Service Solutions (SPSS) dari N=51 memperoleh hasil 0,496, lebih besar dari Harga Kritik dari Spearmen, N=30 dengan tingkat kepercayaan 95\% yaitu 0,364 berarti secara bersama-sama terdapat pengaruh yang signifikan antara variabel Presepsi Karier (X1) dan variabel Kedisiplinan (X2) terhadap variabel Prestasi Kerja (Y).

\section{KESIMPULAN}

1. Terdapat pengaruh sedang $(0,456)$, antara Presepsi Karier terhadap Prestasi Kerja dimana tiga indikator yang terendah dari variabel Persepsi karier adalah: Dunia Pendidikan dapat menjanjikan suatu peningktan karier; Perencanaan sesuai dengan pelaksanaan keprofesionalan; Dalam meniti karier seorang guru harus memiliki suatu pengetahuan

2. Terdapat pengaruh sedang $(0,443)$, antara Kedisiplinan terhadap Prestasi Kerja dimana indikator yang terendah dari variabel kedisiplinan adalah Mengisi daftar hadir

3. Terdapat pengaruh sedang $(0,496)$, antara Persepsi karier dan Kedisiplinan terhadap Prestasi Kerja dimana indikator yang terendah dari variabel kedisiplinan adalah Mempertahankan pengambilan nilai.

\section{SARAN}

1. Sekolah tersebut harus mempunyai tekat untuk meningkatkatkan karier 
para guru karena ada tiga indicator yang nilainya paling rendah.

2. Kedisiplinan masih harus ditingkatkan mengingat indicator pengisian daftar hadir masih mmpunyai nilai sangat rendah.

3. Presepsi karier harus ditingkatkan dikarenakan kurang antosiasnya mempertahankan nilai.

\section{DAFTAR PUSTAKA}

Hasibuan, S.P. Melayu, (2000), Managemen Sumber Daya Manusia; Dasar dan Kunci Keberhasilan, CV. Haji Masaaung, Jakarta.

Jurnal Pengembangan Wiraswasta, Volume 12, Nomor 03, Desember 2010, LP2M IPWIJA

Jurnal Pengembangan Wiraswasta, Volume 15, Nomor 03, Desember 2013, LP2M IPWIJA

Jurnal Pengembangan Wiraswasta, Volume 18, Nomor 01, April 2016, LP2M IPWIJA
Nasution, (2008), Teknologi Pendidikan, PT Bumi Aksara, Jakarta.

Bhuono Agung Nugroho, (2005). Strategi Jitu (Memilih Metode Statistik Penelitian dengan SPSS. Yogyakarta: Andi.

Prabu Anwar, (2004), Manajemen Sumberdaya Manusia Perusahaan, Rosda, Bandung.

Prayitno, Dwi, Statistical Product and Service Solution, (2008), Mediakom, Yogyakarta.

Singgih Santoso, (2010), BukU Latiha SPSS, Edisi Kedua, PT. Elex Media Komputindo, Jakarta.

Sugiyono, (2005), Statistik untuk Penelitian, Alfabeta, Bandung.

Sukardi HM, (2008), Evaluasi Pendidikan Prinsip \& Operasionalnya, PT Bumi Aksara, Jakarta.

Wahab, Abdul Aziz, (2008) Anatomi Organisasi dan Kepemimpinan Pendidikan, Alfabeta, Bandung

Yayat Hayati Djatmiko, (2008), Prilaku Organisasi, Alfabeta, Bandung 